\title{
62. 先行車の挙動把握への鉛直面照度の影響
}

\author{
石渡正紀 斎藤孝 阪口敏彦 \\ (松下電工株式会社)
}

【はじめに】高速道路での事故要因比率を調査すると先行車が絡んだものが圧倒的に多い!。近年，設計 速度が $140 \mathrm{~km} / \mathrm{h}$ の高速道路の建設が予定されており，走行時の運転者の視環境が激変することが予想され る。これにともない先行車の絡んだ事故がさらに増加する可能性がある。これを照明によって低隇するため の第一段階として, 我々は, 先行車の挙動把握のしやすさ (先行車の相対速度の認識しやす巳) と道路進行 方向の鉛直面照度（先行車の背面輝度）との関係を被験者実験によって明らかにした。最終的には先行車の 挙動把握のしやすい照明要件を提案することを目的とする。

【実験概要】本実験は, 運転者から見える先行車と路面の様子をコンピュータグラフィクス（以下 C G) で再現した動画を用い，その動画を300インチの大型スクリーンに投影して実施した。

被験者は暗闇に目を順応させてから実験を開始した。実験が開始されると，先行車が接近してくる2 種類 の動画が（2秒間の暗闇を挟んで） 5 秒間ずつ被験者に呈示された。これら 2 種類の動画のうち,一方の動 画の先行車の速度は常に一定で，もう一方は10段階に変化させた。被験者はこの 2 種類の動画を観察し，ど ちらの先行車の速度が速かったかを二者択一の強制選択で応答した。実験者は得られたデー夕から先行車の 各速度差ごとに正答率を求め, この正答率が $75 \%$ となる速度差を先行車の速度差認識閾值と定めた。この作 業を 4 種類の先行車背面輝度に対して実施した。被験者は視覚正常な男性 5 名（平均31.4歳）であった。

\section{【実験条件】}

・平均路面輝度 : $10.0 \mathrm{~cd} / \mathrm{m}^{2} \quad$ （トンネルを想定）

. 車線軸均斉度: 0.7

·先行車までの距離：80mの距離から連続的に接近

·自車走行速度 : $140 \mathrm{~km} / \mathrm{h}$

. 先行車背面輝度* : $0.9,1.5,2.2,3.8 \mathrm{~cd} / \mathrm{m}^{2}$

※先行車の背面輝度は器具の距離に依存して変化させた

上記の值は時間的な平均值である (図 2 参照)

【実験結果】図 3 に被験者 5 名の平均結果を示す。縦軸は被 験者に呈示された 2 種類の先行車の速度差認識間值であり，そ の数值が大きいほど先行車の速度差が認識しづらいことを意味 している。また，横軸は実測された C G の先行車背面輝度（図 2 の円内）を示す.

図 3 から, 先行車の速度差の認識課題には先行車背面の輝度 值が影響することがわかった。また，これらの関倸には速度差 認識がしづらくなるピーク $\left(2.0 \mathrm{~cd} / \mathrm{m}^{2}\right.$ 付近）が存在することも 示唆された。人間の視覚情報処理において，「対象物の見え」 を認識するためには, 背景とその対象物との輝度対比が用いら れ，これがその後の視覚情報処理の基本的な入力になる。今回 のような先行車の速度差の認識課題は, さらに高次レベルの視 覚情報処理であるため, 輝度対比は重要な要因であると考えら れる．今後はこの輝度対比の影響を把握するため，様々な背景 輝度分布でのデー夕を集め, 照明の影響を考慮した先行車の挙 動把握モデルを構築する予定である。

【まとめ】先行車背面を照らす道路進行方向の鉛直面照度を 制御することによって, 先行車の挙動把握がしやすい, より安 全な道路視環境が得られることがわかった。

参考文献

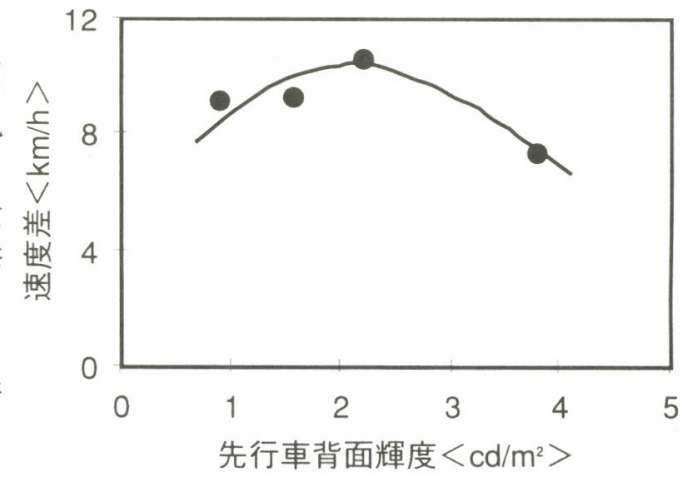

図 3 被験者 5 名の平均結果

1）伊東豊治他：高速道路と自動車, Vol.37, No.11 page.49-54 1994

The effect of vertical illuminance on grasping behavior of precedence car Masaki Ishiwata, Takashi Saito, Toshihiko Sakaguti 